\title{
PROPERTY RIGHTS IN THE CURRENT CONTEXT
}

\author{
Loredana Adelina PĂDURE*
}

\begin{abstract}
You may wonder what property rights have to do with economics. Your property--your house, your car, your pets--are items you buy and own. There are also intellectual property rights such as copyright, patents, etc. Many of these rights are laid out in the U.S. Constitution and have been confirmed, extended, or limited by the courts. American people take for granted that they can do what they want with that property, at least up to a point. You can paint the walls inside a house you own any color you like, including hot pink or all black. However, there may be rules set out by a community about paint colors for the exterior of your home, which can offend or lower house values for other homes nearby. These by-stander effects from what you do with your property are called externalities. In this context, many rights on private property were affected. The massive closure of restaurants, cafes, cinemas and other crowded places has resulted in significant losses for business owners. All these rights are of owners.
\end{abstract}

Keywords: property rights; economic growth; externalities

DOI: 53373 / REDS.2021.53.4.055

Other examples of how property rights intersect with economics are: If you have a patent, can someone elsewhere in the country or even elsewhere in the world copy and benefit from your idea without compensating you? Can a town take over your house and land and use it to build a mall even if you don't want to sell out (called eminent domain)? Do you own your kidneys and can you buy or sell one? Do you own your children until they reach a legally-defined age?

To economists, property rights are an example of an underlying economic institution. The behind-the-scenes laws and customs turn out to matter a great deal in the economic health, growth, and wellbeing of an economy and its citizens. Different sets of rules and laws about how a person may acquire, change, benefit or profit from, and dispose of various kinds of property affect everything from the daily lives of citizens to the growth and prosperity of a country to international relations.

Economic systems such as communism have drastically different concepts of individual rights to property. The consequences on incentives may be more obvious when comparing two very different economic views of property rights, but small differences also turn out to matter.

Property Right is the exclusive authority to determine how a resource is used, whether that resource is owned by government or by individuals. Society approves the uses selected by the holder of the property right with governmental administered force and with social ostracism. If the resource is owned by the government, the

* Assoc. Prof. PhD., Hyperion University, Bucharest. 
agent who determines its use has to operate under a set of rules determined, in the United States, by Congress or by executive agencies it has charged with that role....

It is not normal that the absolute nature of the property right be altered in a situation like ours. case it is required by the interests of the state or society. There is a direct organic connection between property rights and its restrictions. The possibility of restricting the right to private property in the interests of society is provided both at the international level and nationally - by our Constitution. These regulations give rise to restrictive measures on owners' rights. For example, during the pandemic and the quarantine imposed to prevent large crowds, numerous restaurants and cafes, shops and malls, entertainment venues and cinemas, were closed, public transport was banned, many flights were cancelled etc. It is obvious that such measures have resulted not only in a negative impact on the economy, but also in causing significant losses in the form of lost profits for the owners of such institutions, as well as their suppliers.

What happens when property rights don't exist? The Tragedy of the Commons, by Garret Hardin ${ }^{1}$. In 1974 the general public got a graphic illustration of the "tragedy of the commons" in satellite photos of the earth. Pictures of northern Africa showed an irregular dark patch, 390 square miles in area. Ground-level investigation revealed a fenced area inside of which there was plenty of grass. Outside, the ground cover had been devastated.... The explanation was simple. The fenced area was private property, subdivided into five portions. Each year the owners moved their animals to a new section. Fallow periods of four years gave the pastures time to recover from the grazing. The owners did this because they had an incentive to take care of their land. But no one owned the land outside the ranch. It was open to nomads and their herds....

Private Property and Opportunity Costs, by Dwight Lee ${ }^{2}$

Too Costly to Drive: Assume you win a Rolls Royce Silver Shadow, with insurance, maintenance, gas, and taxes paid. While this isn't quite as nice as winning the state lottery, the going price for a Silver Shadow is around $\$ 250,000$. That's the good news. The bad news is that you're probably not wealthy enough to drive this car. Your first reaction is likely: What do you mean I can't afford to drive it? Everything is paid for by someone else. True, but I still predict that you will find the car too costly to drive. Regardless of how you got the Rolls Royce, the cost of driving it is the price someone else is willing to pay for it. And because the car is your private property, you can't ignore that cost....

Justice and Private Property

Philosophy professor Chris Freiman discusses the concept of private property, addressing both its critics and its advocates, and how it relates to justice.

Karol Boudreaux on Wildlife, Property, and Poverty in Africa

\footnotetext{
${ }^{1}$ the Concise Encyclopedia of Economics

${ }^{2}$ At CommonSenseEconomics.com. From The Freeman.
} 
Karol Boudreaux, Senior Research Fellow at the Mercatus Center at George Mason University, talks with EconTalk host Russ Roberts about wildlife management in Africa. Their conversation focuses on community-based wildlife management in Namibia, a policy to give communities the incentives to protect wildlife and avoid the tragedy of the commons....

The most important concept in all of economics is property rights. Most of what people do can be explained in terms of establishing, protecting and maximizing the value of personal property. The property may be real estate, or it may be intellectual property like a copyright or trademark (or, these days, even a patentable "business process.").

Or it might be a parking space. Observing how parking spaces are allocated in Chicago provides a fundamental lesson in property rights economics....

The Tragedy of the Commons

Sean Mullholland explains the tragedy of the commons and two potential solutions to problem: public ownership by government or private ownership.

Satire illustrating a common logical pitfall about property rights and voluntary exchange: Your Dog Owns Your House

Did you know that your dog owns your house, or rather some portion of it? If this is not immediately obvious to you, you will find it helpful to consider some aspects of the ethics and economics of redistribution. Your dog is alert, plucky and a fearsome guardian of your property. For all we know, without his services, you would have been burgled over and over again. Your belongings would be depleted and the utility you derived from your home would be much reduced. The difference between the actual value of your home and its unguarded value is the contribution of your dog, and so is the difference between the respective utilities or satisfactions you derive from it....

Richard Epstein on Property Rights and Drug Patents ${ }^{4}$

Richard Epstein of the University of Chicago and Stanford University's Hoover Institution talks about property rights, drug patents, the FDA, and the ideas in his latest book, Overdose: How Excessive Government Regulation Stifles Pharmaceutical Innovation from Yale University Press....

The Economics of Organ Donations.

Russ Roberts and Richard Epstein, law professor at the University of Chicago, discuss the market for kidneys. Should people be allowed to buy and sell kidneys? How might a market for kidneys actually work in practice? Should mercenary motives be allowed to trump altruism? Epstein deals with these questions and more.

How Free-Market Kidney Sales Can Save Lives-And Lower the Total Cost of Kidney Transplants ${ }^{5}$

\footnotetext{
${ }^{3}$ Anthony de Jasay on Econlib.

${ }^{4}$ Podcast on EconTalk, February 2007.

${ }^{5}$ Kathryn Shelton and Richard B. McKenzie
} 
The recent conviction of a New York man for brokering the sale of black-market kidneys has economists and the general public alike rethinking the 1984 National Organ Transplant Act. This law prohibits the free trade of human organs, including, according to President Obama's Department of Justice (DOJ), bone marrow. However, a three-judge panel of the Ninth Circuit Court of Appeals ruled unanimously in Doreen Flynn at al. v. Holder that bone marrow donors could be compensated. Part of their reasoning involved the idea that if the government's argument (against compensation) were upheld, then the 1984 law "would prohibit compensating blood donors." The Obama Justice Department is now seeking a hearing by the full Ninth Circuit. What is the DOJ's argument? That bone marrow should not be subject to "market forces" because the resulting price of bone marrow would undermine voluntary donations and price many prospective recipients in need of transplants out of life-saving operations.

Michele Boldrin on Intellectual Property

Michele Boldrin of Washington University in St. Louis talks with EconTalk host Russ Roberts about intellectual property and Boldrin's book, co-written with David Levine, Against Intellectual Property. Boldrin argues that copyright and patent are used by the politically powerful to maintain monopoly profits. He argues that the incentive effects that have been used to justify copyright and patents are exaggerated--few examples from history suggest that the temporary and not-sotemporary monopoly power from copyright and patents were necessary to induce innovation. Boldrin reviews some of that evidence and talks about the nature of competition.

The Struggle Over Intellectual Property

It's a high-stakes tussle between technology and the law, highlighted by tens of millions of file traders thumbing their noses at legal restrictions. True, Napster's court imbroglio may have cost it a third of its users....

Is it legal for Google to scan millions of copyrighted books without asking permission? Is it economically efficient? Is Google Book Search "Fair Use"?, ${ }^{6}$

So, everyone knows about this company, Google. Some of you might have heard about this project, which Google announced last December, 2004, called Google Print, and that they renamed in November, 2005 the Google Book Search project.... They imagine to take books and to make it possible for people to see inside.... $9 \%$ of those books are books that are copyrighted and still in print; $16 \%$ of those books are books that are in the public domain-meaning books whose copyright has expired. And that means that $75 \%$ of the 18 million books that Google originally intended to copy and then index are books that are under copyright in the United States but out of print....

Heller on Gridlock and the Tragedy of the Anticommons. EconTalk podcast.

Michael Heller of Columbia Law School and author of The Gridlock Economy talks to EconTalk host Russ Roberts about the book and the idea that fragmented

${ }^{6}$ Lawrence Lessig. Video at YouTube (30 min.) 
ownership is a barrier to innovation. Heller makes an analogy between the tragedy of the commons and what he calls the tragedy of the anticommons--the problem of bundling together numerous individual claims to a resource. Examples discussed include drug innovation when the innovator wants to use technologies of multiple patent holders, new music or visual media where the creator wants to use multiple copyrighted works, and allocation of spectrum rights and its role in wireless innovation....

Richard Epstein on Property Rights and Drug Patents. EconTalk podcast.

Richard Epstein of the University of Chicago and Stanford University's Hoover Institution talks about property rights, drug patents, the FDA, and the ideas in his latest book, Overdose: How Excessive Government Regulation Stifles Pharmaceutical Innovation from Yale University Press.

How Property Rights Solve Problems, ${ }^{7}$

Should restaurants allow smoking or not? Should schools teach evolution or intelligent design or both? Should insurance companies cover contraception? Should I be able to take off my shoes in your living room?...

Eminent Domain: Debate Pits Private Property Against Powers of the State, from Econoblog at the Wall Street Journal

The closely watched case centers on a New London, Conn., economic development plan. The city wants to use eminent domain to build offices, a hotel, condominiums and parking where houses now stand, arguing that its plan has economic benefits in new jobs and property-tax revenue. But opponents maintain that the project isn't a legitimate public use, saying it unjustly takes private property for a project that will benefit other private interests....

Richard Epstein on Property Rights, Zoning, and Kelo. EconTalk podcast.

Richard Epstein, of the University of Chicago and Stanford's Hoover Institution, makes the case that many current zoning restrictions are essentially "takings" and property owners should receive compensation for the lost value of their land. He also discusses the Kelo case and the political economy of the regulation of land.

EMINENT DOMAIN, an original ownership retained by the sovereign, or remaining in the state, whereby land or other private property can be taken for the public benefit. This is the most definite principle of fundamental power of the government with regard to property, and the most striking example of the sovereignty of the people as a corporate body to resume original possession of the soil, where its use is essential to their mutual advantage and the welfare of society....

The Law, by Frederic Bastiat. ${ }^{8}$

I do not use it, as is so often done, in a vague, indeterminate, approximate, or metaphorical sense; I use it in its precise, scientific sense, as expressing the idea opposed to that of property. When property is transferred without the consent of its

\footnotetext{
${ }^{7}$ David R. Henderson. On Econlib.

${ }^{8}$ Chapter 2 in Selected Essays on Political Economy
} 
owner and without compensation, whether by force or by fraud, from the one who possesses it to anyone who has not created it, I say that property rights have been violated, that plunder has been committed. I say that this is precisely what the law is supposed to suppress always and everywhere. If the law itself commits the act that it is supposed to suppress, I say that this is still plunder and, as far as society is concerned, plunder of an even graver kind. In this case, however, it is not the one that profits from the act of plunder who is responsible for it; it is the law, the legislator, society itself, and it is in this that the political danger consists....

Strategies to handle water pollution, historical and modern: Bruce Yandle on the Tragedy of the Commons and the Implications for Environmental Regulation,

Bruce Yandle of Clemson University and George Mason University's Mercatus Center looks at the tragedy of the commons and the various ways that people have avoided the overuse of resources that are held in common. Examples discussed include fisheries, roads, rivers and the air. Yandle talks with EconTalk host Russ Roberts about the historical use of norms, cooperative ventures such as incorporating a river, the common law, and top-down command-and-control regulation to reduce air and water pollution.

Slavery: The American Founding in Practice.

History professor Rob McDonald of the U.S. Military Academy at West Point gives a lecture on the conflict between the ideals of the American Revolution, such as individual liberty, and unfortunate realities of the time, such as slavery.

Property rights, incentives, and slavery throughout history: Stanley Engerman on Slavery

Stanley Engerman of the University of Rochester talks about slavery throughout world history, the role it played (or didn't play) in the Civil War and the incentives facing slaves and slave owners. This is a wide-ranging, fascinating conversation with the co-author of the classic Time on the Cross ${ }^{9}$ and the forthcoming Slavery, Emancipation, and Freedom (LSU Press, 2007). Engerman knows as much as anyone alive about the despicable human arrangement called slavery and the vastness and precision of his knowledge is on display in this interview.

Copyright, in Lalor's Cyclopedia of Political Science

COPYRIGHT is the name of a certain species of incorporeal property. It is the exclusive right of receiving the profits from publishing and selling works of literature and art....

Property and the Law, by Frederic Bastiat. Chapter 3 in Selected Essays on Political Economy on Econlib

I ask whether the right to property is not one of those rights which, far from springing from positive law, are prior to the law and are the reason for its existence....

Historic Self-Preservation, ${ }^{10}$

${ }^{9}$ co-authored with Robert Fogel

${ }^{10}$ Fred S. McChesney. Econlib, January 7, 2002. 
Government control over private owners' use of their property empowers politicians to advance their own agendas. In particular, it allows politicians to threaten property owners with historic preservation status when the conditions do not justify political intervention....

Information Goods, Intellectual Property Archive. Related articles and links on EconLog. We transact exchanges efficiently because both parties agree on the property rights relevant to them. Both of us acknowledge that the watermelons, stacked neatly by the roadside, are "owned" by the salesman, or by the person or firm for whom he acts as agent. Both of us also acknowledge that I have the rights of disposition over the money in my pockets or in my bank account. Furthermore, both of us recognize that any unilateral attempt to violate these assigned rights of exclusion will be subject to penalty through the arms and agencies of the state. In other words, both of us agree on what "the law" is that is relevant to the exchange in question....

Property and Property Rights, by Anthony de Jasay. On Econlib.

Ironically, the author who has done the most to impose the term "property rights" on scholarly usage was Armen Alchian, an economist of irreproachable credentials both as a fine theorist and a defender of the free society. In a seminal essay that has become a foundation stone of "property rights economics", he explained that when you owned, say, a piece of land, what you had was the right to leave it fallow, to plough it, to grow wheat on it for your own use or for sale, to walk across it, to fly over it, to build a house on it, to grant an easement on it, to lease it to another party, to bequeath or to sell it. Property was such a "bundle of rights". It is tempting to hold that if you removed one stick from the bundle, it remained a bundle, if you removed two, it still remained a bundle; How many sticks can one remove without the remainder ceasing to represent property, and are some sticks more essential than others?...

Property and its Enemies. Part I. "Design Faults" in Locke's Theory of Property Taint Ownership with Guilt, by Anthony de Jasay. On Econlib.

Ownership is a relation between an owner and a scarce resource, such that the owner is at liberty to use and alienate it, exclude all others from access to it except by his consent, and thus also at liberty to grant various kinds of prior claims and use rights in it for those towards whom it assumes contractual obligations. It is doubtful whether ownership, even ownership by a collective entity, has any meaning without some element of exclusion that separates owners from non-owners of the resource in question. When everybody owns a thing, nobody owns it....

Property Rights and Natural Resource Management, by Richard Stroup and John Baden. On Econlib.

How much development should be allowed on the Yellowstone River? Is oil being used too quickly? Is the strip mining of coal properly controlled?

In analyzing such natural resource issues, it is critically important for us to consider the form and ownership of property rights in resources. Whether the perspective is historical, predictive, or prescriptive, it is important to recognize who 
controls these property rights, and under what conditions. Only from this framework of property rights can we understand decision processes. Individuals, not large groups or societies, make the decisions. They do so, however, in an institutional framework. The property rights paradigm provides important analytical leverage in comprehending how individuals interact within institutions. The property rights concept, then, not only helps us understand history; it also helps us predict the consequences of today's institutions or to compare the likely outcomes of alternative arrangements....

Ronald Coase ${ }^{11}$

Ronald Coase received the Nobel Prize in 1991 "for his discovery and clarification of the significance of transaction costs and property rights for the institutional structure and functioning of the economy." Coase is an unusual economist for the twentieth century, and a highly unusual Nobel Prize winner. First, his writings are sparse. In a sixty-year career he wrote only about a dozen significant papers--and very few insignificant ones. Second, he uses little or no mathematics, disdaining what he calls "blackboard economics." Yet his impact on economics has been profound. That impact stems almost entirely from two of his articles, one published when he was twenty-seven and the other published twenty-three years later.

\section{Bibliography:}

- Aguiar Ribeiro Do Nascimento G., The Long Road to the International Recognition of Economic and Social Rights: The Right to an Adequate Standard of Living. The Age of Human Rights Journal, (11), 43-60., 2018

- Karol Boudreaux on Property Rights and Incentives in Africa, EconTalk podcast. Dec. 17, 2007.

- Parking space rights after blizzards: Snow Jobs, by Fred S. McChesney. Econlib, October 15, 2001

- The Bases for Freedom in Society, by James M. Buchanan. Chapter 2 in The Limits of Liberty: Between Anarchy and Leviathan. On Econlib.

\footnotetext{
${ }^{11}$ A biography from the Concise Encyclopedia of Economics
} 